\title{
Head and neck squamous cell carcinoma and its correlation with human papillomavirus in people living with HIV: a systematic review
}

\author{
Manuela Ceccarelli ${ }^{1}$, Emmanuele Venanzi Rullo ${ }^{1}$, Alessio Facciolà ${ }^{1}$, Giordano \\ Madeddu², Bruno Cacopardo ${ }^{3}$, Rosaria Taibi ${ }^{4}$, Francesco D'Aleo ${ }^{1}$, Marilia Rita \\ Pinzone $^{5}$, Isa Picerno ${ }^{6}$, Michele di Rosa7, Giuseppa Visalli 6 , Fabrizio Condorelli ${ }^{8}$, \\ Giuseppe Nunnari ${ }^{1}$ and Giovanni Francesco Pellicanò ${ }^{9}$ \\ ${ }^{1}$ Department of Clinical and Experimental Medicine, Unit of Infectious Diseases, University of Messina, Messina, Italy \\ ${ }^{2}$ Department of Clinical and Experimental Medicine, Unit of Infectious Diseases, University of Sassari, Sassari, Italy \\ ${ }^{3}$ Department of Clinical and Experimental Medicine, Unit of Infectious Diseases, University of Catania, Catania, Italy \\ ${ }^{4}$ Department of Medical Oncology A, National Cancer Institute of Aviano, Aviano, Italy \\ ${ }^{5}$ Department of Pathology and Laboratory Medicine, School of Medicine, University of Pennsylvania, Philadelphia, \\ Pennsylvania, USA \\ ${ }^{6}$ Department of Biomedical and Dental Sciences and Morpho Functional Imaging, University of Messina, Messina, Italy \\ ${ }^{7}$ Department of Biomedical and Biotechnological Sciences, Human Anatomy and Histology Section, University of Catania, \\ Catania, Italy \\ ${ }^{8}$ Department of Pharmacological Sciences, Università del Piemonte Orientale "A. Avogadro", Novara, Italy \\ 'Department of Human Pathology of The Adult and The Developmental Age "G. Barresi", Unit of Infectious Diseases, \\ University of Messina, Messina, Italy
}

Correspondence to: Manuela Ceccarelli, email: manuela.ceccarelli86@gmail.com

Keywords: HNSCC; HIV; head and neck cancer; HPV; papillomavirus

Received: January 29, $2018 \quad$ Accepted: February 27, $2018 \quad$ Published: March 30, 2018

Copyright: Ceccarelli et al. This is an open-access article distributed under the terms of the Creative Commons Attribution License 3.0 (CC BY 3.0), which permits unrestricted use, distribution, and reproduction in any medium, provided the original author and source are credited.

\section{ABSTRACT}

Over the last 20 years we assisted to an increase in the mean age of People Living with HIV and their comorbidities. Especially, there was an increase in Human Papillomavirus-related head and neck squamous cell carcinomas. Despite their increasing incidence in HIV-positive people, mechanisms that lead to their development and progression are only partially understood.

The aim of this review is to identify key data and factors about HPV-related head and neck squamous cell carcinoma in HIV-seropositive patients. Systematic search and review of the relevant literature-peer-reviewed and grey-was conducted using the Preferred Reporting Items for Systematic Reviews and Meta-analysis (PRISMA) guidelines. We included in our review only the $\mathbf{3 5}$ full-text articles we considered the most substantial. It is mandatory to improve our knowledge about the interactions existing between HPV and HIV, and about their actions on oral mucosa immune system.

\section{INTRODUCTION}

Over the last 20 years, the so-called post-highly active antiretroviral therapy (post-HAART) era, we assisted to an increase in the mean age of People Living
With HIV (PLWH) and comorbidities related to ageing, immune suppression and persistent inflammation [1-65]. Especially, there was an increase in HPV-related oral lesion incidence in HIV-positive persons, including a subset of head and neck squamous cell carcinomas (HNSCC) [6669]. A higher incidence of tobacco and alcohol use has 
been reported among HIV-positive persons, along with sexual risk behaviors, occurring in suboptimal immunestatus even in the presence of combined Anti-Retroviral Therapy (cART). Therefore, even though in the past it was hypothesized that Highly Active Anti-Retroviral Therapy (HAART), and in particular the use of Protease Inhibitors (PIs), could be accounted for the increase of oral HPV infection and, as a consequence, of HNSCC, it is still not clear if this increase is related to behaviors, to disease factors or to a combination of all them [69-76].

The aim of this review is to identify key data and factors about HPV-related HNSCC in HIV-seropositive patients, and to provide a stepping stone for further studies aimed to clarify the relationship existing between HIV, HPV and HNSCC.

\section{PHYSIOPATHOLOGY}

Despite HNSCCs increasing incidence in PLWH, mechanisms that lead to their development and progression are only partially understood. Substance use and immunosuppression are still under investigation as the variables most frequently associated with their presence $[66,75]$, even though molecular and epidemiological data confirm the involvement of HighRisk HPV (HR-HPV) in the physiopathology of HNSCC, particularly those localized to the lateral wall of the oropharynx, the base of the tongue and tonsils [77-82]. Other variables, such as irradiation, are currently under investigation [83].

$\mathrm{HPV}$ is a DNA virus that can cause lesions anywhere on the cutaneous surface, including the extremities, genitalia and oral mucosa, and establish a persistent oral infection caused by reduced infection clearance and an increased viral load, seen as the presumed precursor for HPV-related oropharyngeal squamous cell carcinoma [81, 84]. However, it cannot establish an infection in healthy skin or mucosa [85]. HPV-DNA can be found in most of HIV/AIDS-associated oral cancer cells, suggesting that HIV can act as a promoter in the onset of HNSCC, disrupting oral mucosa cells' immune functions [76]. As a matter of fact, HIV protein tat activates a pathway linked to NF- $\kappa \mathrm{B}$, involving pro-inflammatory cytokines IL-12, IL-6, IL-8 and TNF- $\alpha$ which, when secreted in HIVinfected intraepithelial macrophages and dendritic cells induce apoptosis and disruption of their barrier function [85]. A high concentration of IL-12, IL-6, IL-8 and TNF- $\alpha$ can be found in saliva of PLWH with malignant or premalignant oral lesions [76]. NF- $\mathrm{B}$ also upregulates HPV proteins E6 and E7, stimulating their continuous transcription, thus facilitating the progression of HPVrelated neoplasms through the inactivation of $p 53$ and $p R B$ $[72,85,86]$. Likewise, HIV-tat activates HPV replication, its proteins' expression and the proliferation of HPVinfected keratinocytes. Other HIV proteins, such as Rev and $V p r$, enhance HPV oncogenic activity, stimulating L1 overexpression in epithelial cells or inducing a cell cycle arrest [85].

Moreover, a recent study by Walline et al demonstrated that HPV-related HNSCC express a higher title of the oncoprotein p16 and a lower title of the oncoproteins $\mathrm{pRB}$ and $\mathrm{p} 53$, even though oncoprotein $\mathrm{p} 53$ could be mutant in some subsets of HPV-related HNSCC, usually more aggressive than those expressing a wild type p53 oncoprotein [87].

It appears clear that further studies are required to understand the pathogenesis of HPV-related HNSCC in PLWH.

\section{RISK FACTORS}

The incidence of the HNSCC, particularly those associated to oral HPV infection, has been increasing in people living with HIV in the last 20 years. HPV-related HNSCC have been found to have a Standardized Incidence Ratio (SIR) of 3.2 (95\% CI = 2.5-3.4), significantly higher than the general population [79]. HIV-infected persons have, as a matter of fact, a 2-3-fold higher prevalence of oral HPV-infection, compared to the general population, with a highly-variable frequency of high-risk serotypes $[67,84]$. Likewise, the incidence of HPV-related HNSCC in PLWH is 2 to 6 times higher than the one in the general population $[75,79,88,89]$.

In this section, we report on the potential risk factors associated to this increase.

\section{Age}

During the pre-HAART era, the incidence of HNSCC increased for males aged 40-64 years, while decreasing for males aged 65 years or older [75]. After the introduction of HAART, it seems that this trend has been diverted. As a matter of fact, studies by Beachler et al [68], and Anaya-Saveedra et al [90], demonstrated that the risk for oral HPV infection, HPV oral lesions (HPVOLs) and HPV-related HNSCC increases with age. This diverted trend, with an HNSCC incidence increasing with age, had also been observed by Chaturvedi et al in 2009 [91], when they associated the prolonged survival of HIVinfected individuals to the increased incidence of some neoplasms, and by Kreimer et al $[82,92]$ in two distinct works establishing the incidence and risk factors of HPVOLs and multiple HPV-seropositivity. On the other hand, a study by Ciarrocca et al [81] demonstrated that HPVrelated HNSCC are associated with younger age. Further studies are needed to understand the role of age in the onset of HNSCC.

\section{Tobacco and alcohol use}

PLWH have increased exposure to tobacco and alcohol, which are major risk factors for both the HPVrelated HNSCC and the HPV-unrelated HNSCC, compared 
to the HIV-negative populations [69, 76, 79]. It is known that cigarette smokers have a higher oral HPV prevalence, maybe due to a reduced clearance of the virus, or to an increased HPV viral replication and, as a consequence, a higher viral load, as PLWH have [66, 68, 75, 81, 93]. A reduced clearance of the HPV because of tobacco smoking and alcohol use could be one of the reasons why PLWH have a higher incidence of HNSCC. Moreover, tobacco smoking and alcohol are known agents of oral epithelial damage with a continuous pro-inflammatory activity, which is enhanced by the presence of HIV. Thus, the disruption of the mucosal barrier caused by these agents contribute to the establishment of a chronic HPV infection $[73,85]$.

\section{Sexual behavior}

As HPV-related HNSCC are caused by the presence of HPV in the oral mucosa, the behaviors that enable HPV to reach the oral cavity and infect the mucosa have to be considered risk factors for HNSCC. An high number of sexual oral partners, as in active fellatio, cunnilingus or rimming, recently or in lifetime, is associated with an high risk of oral HPV infection [68, 75, 81, 82, 92-94]. Moreover, Syrjänen et al [85] demonstrated that PLWH have an higher incidence of high-risk HPV (HR-HPV) serotypes. Curiously, a 2013 work by Beachler et al [89] demonstrated that heterosexual men, and not MSM, like previously affirmed by Del Mistro et al [95], are the population with the higher risk of being persistently positive to an oral HPV infection [79, 89, 95]. However, it is still unclear how and in what measure an oral HPV infection by an HR-HPV serotype causes an increased incidence of HNSCC [69].

\section{Immunosuppression}

A decrease in the number of CD4+ T lymphocytes increases the risk of having an oral HPV infection and developing malignancy $[68,71,78,79,82,91,92,94]$, while the number of CD8+ T lymphocytes does not seem to be associated with the incidence of HPV-related HNSCC [79]. Oral cancer in PLWH and lower CD4+ T lymphocyte counts have a high mortality rate [75]. It is hypothesized that a low CD4+ T-cell count, even a CD4+ T-cell count around 300 cells $/ \mu \mathrm{L}$, and even around 350 cells $/ \mu \mathrm{L}$ in some cases, increases the risk of progression to HNSCC partially because reactivation or reacquisition of oral HPV infection, more than a reduced clearance [68, $69,87,89]$. It is supposed, though, that a low number of CD4+ T lymphocytes influences the risk of developing an HNSCC early in the carcinogenesis [79]. Despite the collective agreement, further studies are needed to confirm that the CD4+ T lymphocyte count significantly influences the incidence and prevalence of HPV-related HNSCC and how and when it operates.

\section{Combined anti-retroviral therapy or highly active anti-retroviral therapy (cART or HAART)}

PLWH, and even in those currently assuming cART, have an increased risk to have an oral HPV-infection and, as a consequence, an HPV-related malignancy [90]. It is supposed that this risk steadily increased in the postHAART era because of a prolonged life expectancy: before the introduction of HAART, PLWH developed AIDS and died before the appearance of HPV-related HNSCC $[76,78]$. Even though HAART helps controlling the HIV infection, it seems to not reduce the risk of having an oral HPV infection or developing a HPVrelated lesion [76, 91, 96]. On the contrary, it could even reduce the barrier function of the oral epithelium, increasing the invasiveness, and thus the malignancy, of the HPV-infection [76]. To support this hypothesis, AnayaSaavedra et al [90] demonstrated in 2013 that PLWH with an undetectable viral load had a sixfold risk of presenting HPV-OLs. It is still not clear, though, why the introduction of HAART reduced the incidence of AIDS-defining neoplasms associated with oncogenic viruses (Human Herpes Virus 8, HHV8; Epstein-Barr Virus, EBV), but had little to none impact on the incidence of HPVrelated tumors, in particular HNSCC [80]. New studies are indeed needed to clarify the influence cART has on the development of oral HPV infections and HPV-related HNSCC.

\section{HPV genotypes}

HPV genotypes are divided into two categories, commonly referred to as HR- HPV and Low-Risk HPV (LR-HPV), to identify their ability of causing cancer. There is evidence that, similarly to cervical cancer, but not to anal cancer, the most common HPV genotype found in HNSCC is HPV-16 [94]. Other genotypes frequently involved in HNSCC in PLWH are -18, -31, -40, -51, -55, -83 [70, 97, 98]. Moreover, HIV-infected persons have not only a higher risk for oral HPV infection, but also for a multiple genotype infection, [76], as well as infection with multiple HR-HPV genotypes regardless of recent or past oral sex $[66,75,89]$. It is important to notice though, that the oral HPV-infection is a causal factor in HNSCC, but it does not work alone, as the inability to clear the infection could have a role in developing a neoplasia $[69,70,72$, $76,85]$.

\section{PRIMARY PROPHYLAXIS (VACCINATION)}

Three kinds of vaccine against HPV are available: the quadrivalent Gardasil, against HPV-serotypes 6, 11, 16 and 18; the nine-valent Gardasil-9, against HPV-serotypes $6,11,16,18,31,33,45,52$ and 58; and the bi-valent 
Cervarix, against HR-HPV-serotypes 16 and 18. Even though it is supposed that HPV vaccination can potentially prevent oral HPV infection as well as cervical and anal ones, there are currently no available data about whether a program of vaccination could decrease the incidence of
HNSCC $[66,94]$. Nonetheless, it is imperative to improve HPV vaccination rates, not only among young girls, but also and especially among young and HIV-infected people, so that the incidence of HPV-associated cancersanogenital and oral ones — could be reduced [66, 72, 77].
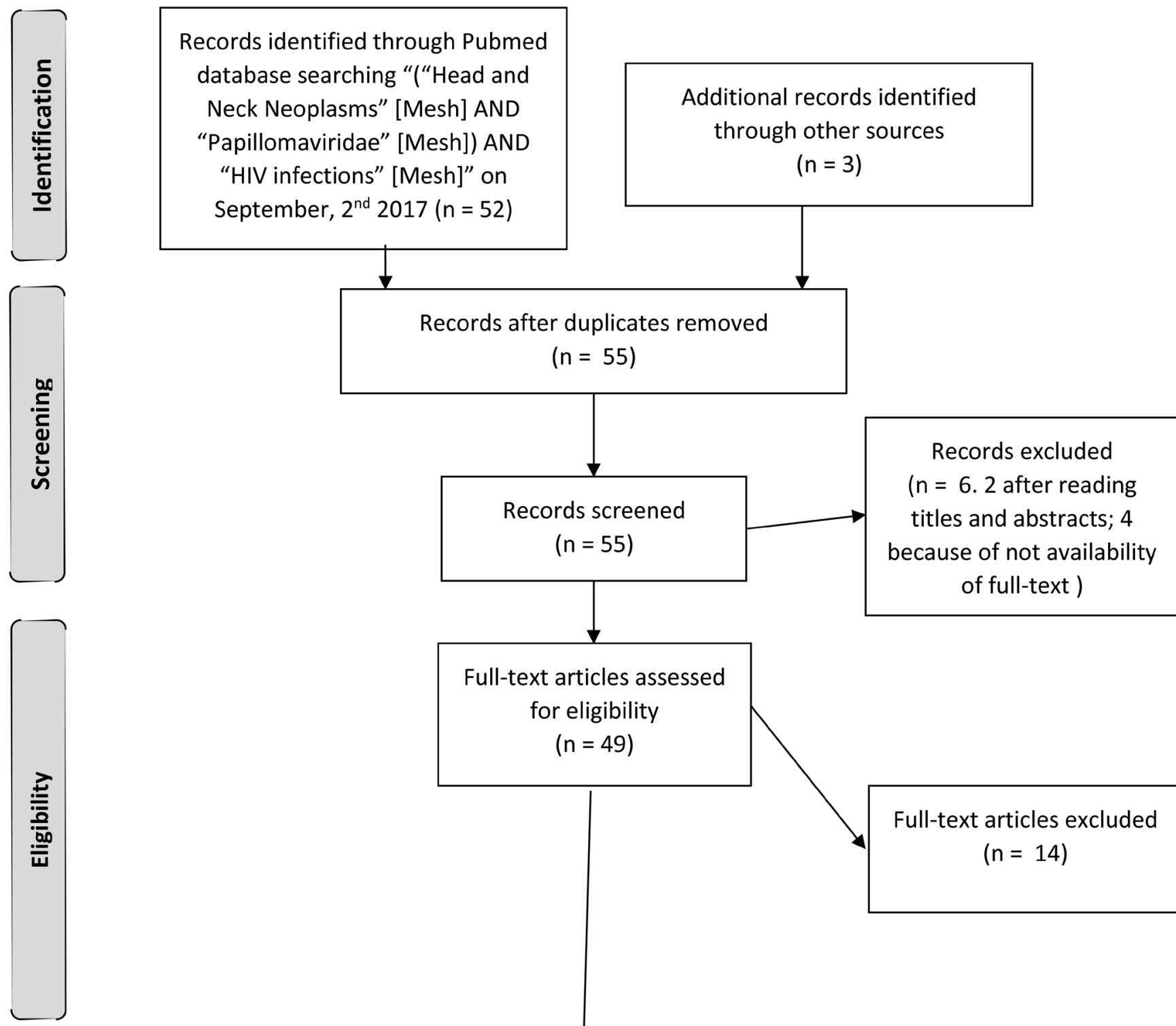

Additional records identified through other sources

$(n=3)$ September, $2^{\text {nd }} 2017(n=52)$
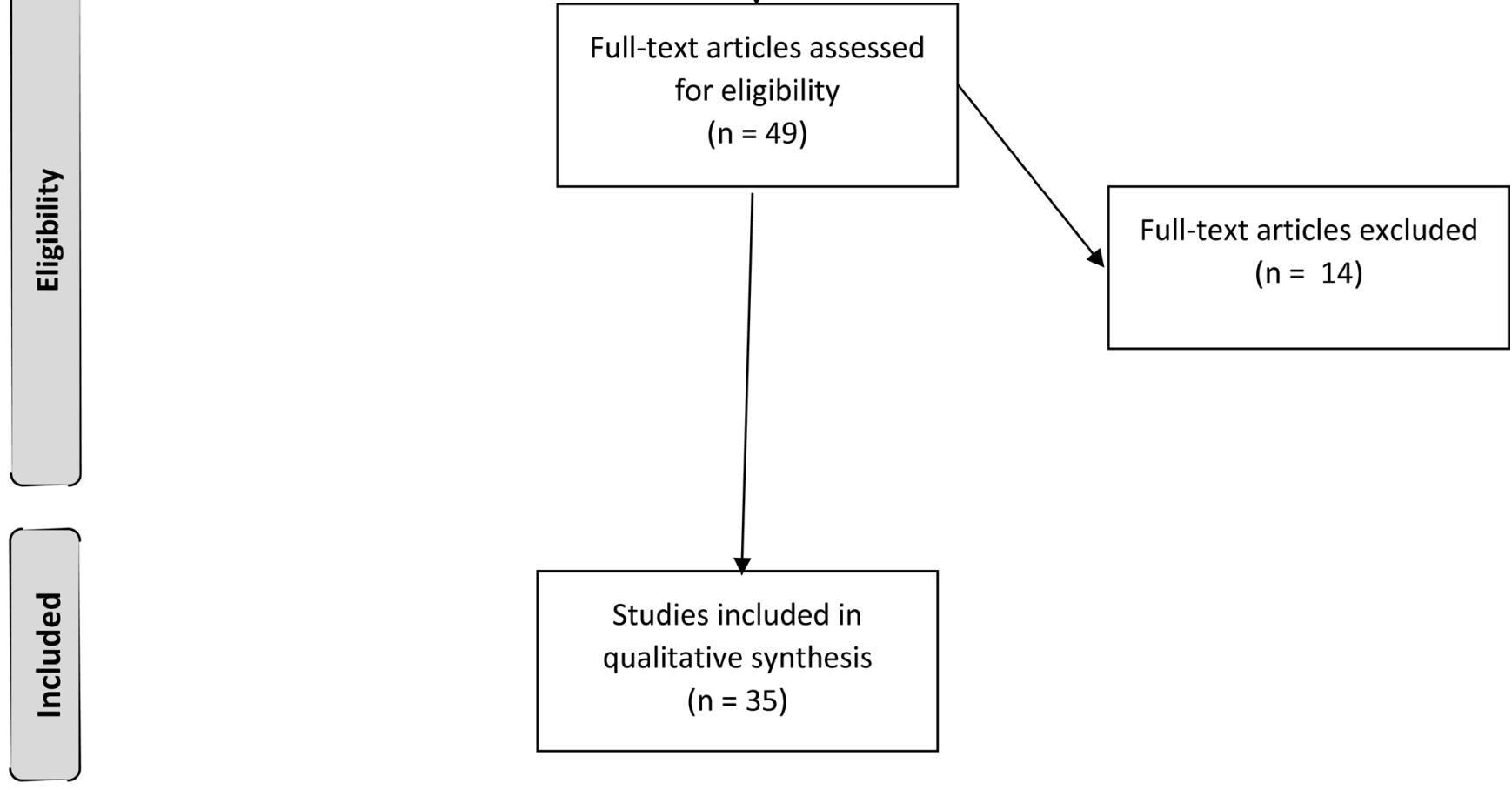

Studies included in qualitative synthesis $(n=35)$

Figure 1: Article assessment diagram. 


\section{SECONDARY PROPHYLAXIS (SCREENING)}

It appears clear how it could be necessary to develop a screening test for HPV-related HNSCC. The two main questions are: what should be the technique employed and who should be the receiving end of the screening?

Some authors suggested that cancer prevention strategies should include patient education and clinical vigilance, beginning with visual assessment and digital palpation of the oral-pharyngeal cavity $[75,96]$. Some authors recommend the use of oral rinses or saliva to determine the presence of a HPV infection, as there is a strong association with HNSCC and a higher sensibility was demonstrated when compared to other sampling techniques [70, 72, 81, 93]. However, oral rinses cannot establish where the infection is localized, while other sampling techniques like brushings and biopsies could offer these data [93].

Seen that they have a higher HPV-infection incidence, PLWH, and above all those who are affected with anal cancer, should be screened and monitored for HPV-related HNSCC [77]. On the other hand, Beachler et al [79] observed that PLWH's risk of developing an HPVrelated HNSCC is only three-fold higher than the general population's, thus a mass-screening policy could not be cost-effective.

Further studies are needed to understand who needs to undergo the screening, and what is the best - the cheapest, with the highest sensitivity - technique to use.

\section{OUTCOMES}

Little is known about the natural history and the treatment outcomes of HPV-related HNSCCs in PLWH [75]. Even though HNSCCs in PLWH are usually more frequent in younger patients, HPV-related ones tend to be usually found in older people and at an advanced stage of both HIV-infection and cancer [69, 76, 79, 88]. Thus, some authors found they have poorer survival rates $(57 \%$ survival rate at 1 year, and $32 \%$ at 2 years) $[76,81,88]$. Moreover, HPV infections in immunocompromised patients are recurrent and recalcitrant to therapy [75]. On the other hand, other authors reported that HPV-related HNSCCs seem to have higher survival rates than HPV-unrelated ones, and that HIV status do not affect the outcome [81, 94]. It seems that $\mathrm{p} 53$ expression could be used as a prognostic biomarker for HNSCC-affected PLWH: those with the lowest expression have the best survival, while those with the highest expression have the poorest survival [87].

\section{MATERIALS AND METHODS}

On September $2^{\text {nd }}, 2017$, we performed a MeSH systematic review of the literature to identify the link existing between Head and Neck Cancer (HNC),
Human Papilloma Virus (HPV) infection and Human Immunodeficiency Virus (HIV) infection. We searched PubMed applying "("Head and Neck Neoplasms" [Mesh] AND "Papillomaviridae" [Mesh]) AND "HIV infections" [Mesh]". We also reviewed the articles references. We limited the inclusion only to articles written in English, published within the last two decades. We identified 55 records and screened them. We excluded 2 articles by title and abstract, because they reported about only one or two queries out of three. Every author independently assessed 49 full-text articles for eligibility. At the end of the assessment we included in our review the 34 full-text articles reporting about HIV-seropositive persons affected by HPV-related HNC we considered the most substantial [66-100] (Figure 1).

\section{CONCLUSIONS}

Despite their current low incidence, HPV-related HNSCC frequency will increase in future, due to the high incidence of HPV oral infection in HIV-infected people. Thus, it is mandatory to improve our knowledge about the interactions existing between HPV and HIV, and about their actions on oral mucosa immune system. Moreover, it is essential to acquire new data about the effects of the vaccination campaign over the incidence of HNSCC. In addition to this, it is required to develop an efficient screening test to determine whether an HPV infection could potentially transform in a malignant lesion. Further studies are needed to achieve these outcomes.

\section{Abbreviations}

Human Immunodeficiency Virus (HIV); People Living with HIV (PLWH); Human Papillomavirus (HPV); Head and neck squamous cell carcinomas (HNSCC); Preferred Reporting Items for Systematic Reviews and Meta-analysis (PRISMA); combined Anti-Retroviral Therapy (cART); Highly Active Anti-Retroviral Therapy (HAART); Protease Inhibitors (PIs); Head and Neck Cancer (HNC); High-Risk HPV (HR-HPV); Deoxyribose Nucleic Acid (DNA); Nuclear Factor kappa-light-chainenhancer of activated B cells (NF- $\mathrm{kB}$ ); Acquired ImmuneDeficiency Syndrome (AIDS); Inter-Leukin (IL); tumor protein p53 (p53); Retino-Blastoma protein (pRB); TransActivator of Transcription (tat); Regulatory of Expression of the Viral genoma (rev); Viral Protein R (vpr); tumor protein p16 (p16); HPV oral lesions (HPV-OLs); Human Herpes Virus 8 (HHV8); Epstein-Barr Virus (EBV); Low-Risk HPV (LR-HPV); men who have sex with men (MSM).

\section{Author contributions}

$\mathrm{MC}$ and GN designed the review; MC and GFP wrote the article; MC, GFP, EVR, AF, GM, BC, RT, FDA, MRP, IP, MDR, GP, FC and GN revised the literature for 
the inclusion in the review; RT, GM and GN revised the manuscript.

\section{CONFLICTS OF INTEREST}

The authors declare that they have no conflicts of interests.

\section{FUNDING}

This research did not receive any specific grant from funding agencies in the public, commercial, or not-forprofit sectors.

\section{Ethical approval}

None required.

\section{Informed consent}

None required.

\section{REFERENCES}

1. Bagella P, Fiore V, Caruana G, Madeddu G. Editorial - Non AIDS-defining malignancies: a new epidemic in HIVinfected population for the upcoming decades? Eur Rev Med Pharmacol Sci. 2017; 21:4744-4745.

2. Smith JA, Nunnari G, Preuss M, Pomerantz RJ, Daniel R. Pentoxifylline suppresses transduction by HIV-1-based vectors. Intervirology. 2007; 50:377-386. https://doi. org/10.1159/000109752.

3. Berretta M, Martellotta F, Di Francia R, Spina M, Vaccher E, Balestrieri L, Borsatti E, Bearz A, De Paoli P, Tirelli U. Clinical presentation and outcome of non-AIDS defining cancers, in HIV-infected patients in the ART-era: the Italian Cooperative Group on AIDS and tumors activity. Eur Rev Med Pharmacol Sci. 2015; 19:3619-3634.

4. Pomerantz RJ, Nunnari G. HIV and GB virus C--can two viruses can be better than one? N Engl J Med. 2004; 350:963-965.

5. Spina M, Berretta M, Tirelli U. Hodgkin's disease in HIV. Hematol Oncol Clin North Am. 2003; 17:843-858. https:// doi.org/10.1016/s0889-8588(03)00046-7.

6. Berretta M, Garlassi E, Cacopardo B, Cappellani A, Guaraldi G, Cocchi S, de Paoli P, Lleshi A, Izzi I, Torresin A, Pietrangelo A, Ferrari M, Bearz A, et al. Hepatocellular Carcinoma in HIV-Infected Patients: Check Early, Treat Hard. Oncologist. 2011; 16:1258-1269.

7. Castronuovo D, Pinzone MR, Moreno S, Cacopardo B, Nunnari G. HIV infection and bone disease: a review of the literature. Infect Dis Trop Med. 2015; 1:e116.

8. Lai V, Zizi B, Vadini F, Calia GM, Bagella P, Fiore V, Peruzzu F, Caruana G, Babudieri S, Mura MS, Madeddu
G. Fib-4 values and neurocognitive function in hiv-infected patients without hepatic coinfections. Infect Dis Trop Med. 2016; 2:e293.

9. Di Benedetto F, Tarantino G, Ercolani G, Baccarani U, Montalti R, De Ruvo N, Berretta M, Adani GL, Zanello M, Tavio M, Cautero N, Tirelli U, Guaraldi G. Multicenter Italian Experience in Liver Transplantation for Hepatocellular Carcinoma in HIV-Infected Patients. Oncologist. 2013; 18:592-599.

10. Nunnari G, Coco C, Pinzone MR, Pavone P, Berretta M, Di Rosa M, Schnell M, Calabrese G, Cacopardo B. The role of micronutrients in the diet of HIV-1 infected individuals. Front Biosci. 2012; e4:2442-2456. https://doi. org/10.2741/556.

11. La Ferla L, Lo Presti Costantino MR, Mondello P. Kaposi's sarcoma in HIV-infected patients: a review of the literature. Infect Dis Trop Med. 2016; 2:e239.

12. Bruno R, Scuderi D, Locatelli ME, Pampaloni A, Pinzone MR. Prevalence of micronutrients deficiencies in a cohort of HIV-positive individuals on ART. Infect Dis Trop Med. 2017; 3:e431.

13. Di Benedetto F, De Ruvo N, Berretta M, Masetti M, Montalti R, Di Sandro S, Ballarin R, Codeluppi M, Guaraldi G, Gerunda GE. Hepatocellular carcinoma in HIV patients treated by liver transplantation. Eur J Surg Oncol. 2007; 34:422-427. https://doi.org/10.1016/j.ejso.2007.05.004.

14. Pinzone MR, Di Rosa M, Cacopardo B, Nunnari G. HIV RNA suppression and immune restoration: can we do better? Clin Dev Immunol. 2012; 2012:515962. https://doi. org/10.1155/2012/515962.

15. Pinzone MR, Berretta M, Cacopardo B, Nunnari G. Epstein-barr virus- and Kaposi sarcoma-associated herpesvirus-related malignancies in the setting of human immunodeficiency virus infection. Semin Oncol. 2014; 42:258-271. https://doi.org/10.1053/j. seminoncol.2014.12.026.

16. Berretta S, Fisichella R, Spartà D, Lleshi A, Nasti G. Primary liver cancer: clinical aspects, prognostic factors and predictive response to therapy. WCRJ. 2015; 2:e561.

17. Buccisano F, Rossi FM, Venditti A, Del Poeta G, Cox MC, Abbruzzese E, Rupolo M, Berretta M, Degan M, Russo S, Tamburini A, Maurillo L, Del Principe MI, et al. CD90/ Thy-1 is preferentially expressed on blast cells of high risk acute myeloid leukaemias. Br J Haematol. 2004; 125:203212. https://doi.org/10.1111/j.1365-2141.2004.04883.x.

18. Pinzone MR, Di Rosa M, Celesia BM, Condorelli F, Malaguarnera M, Madeddu G, Martellotta F, Castronuovo D, Gussio M, Coco C, Palermo F, Cosentino S, Cacopardo B, Nunnari G. LPS and HIV gp120 modulate monocyte/ macrophage CYP27B1 and CYP24A1 expression leading to vitamin D consumption and hypovitaminosis D in HIVinfected individuals. Eur Rev Med Pharmacol Sci. 2013; 17:1938-1950. 
19. Celesia BM, Nigro L, Pinzone MR, Coco C, La Rosa R, Bisicchia F, Mavilla S, Gussio M, Pellicanò G, Milioni V, Palermo F, Russo R, Mughini MT, et al. High prevalence of undiagnosed anxiety symptoms among HIV-positive individuals on cART: a cross-sectional study. Eur Rev Med Pharmacol Sci. 2013; 17:2040-2046.

20. Scarpino M, Santoro M, Pellicanò GF. HIV infection and kidney disease: literature review. Infect Dis Trop Med. 2015; $1:$ e195.

21. Madeddu G, Mameli G, Capobianco G, Babudieri S, Maida I, Bagella P, Rocca G, Cherchi PL, Sechi LA, Zanetti S, Nunnari G, Dessole S, Mura MS. HPV infection in HIVpositive females: the need for cervical cancer screening including HPV-DNA detection despite successful HAART. Eur Rev Med Pharmacol Sci. 2014; 18:1277-1285.

22. Bearz A, Vaccher E, Martellotta F, Spina M, Talamini R, Lleshi A, Cacopardo B, Nunnari G, Berretta M, Tirelli U. Lung cancer in HIV positive patients: the GICAT experience. Eur Rev Med Pharmacol Sci. 2014; 18:500-508.

23. Facciolà A, Venanzi Rullo E, Ceccarelli M, D'Aleo F, Di Rosa M, Pinzone MR, Condorelli F, Visalli G, Picerno I, Fisichella R, Nunnari G, Pellicanò GF. Kaposi's sarcoma in HIV-infected patients in the era of new antiretrovirals. Eur Rev Med Pharmacol Sci. 2017; 21:5868-5879.

24. Simonelli C, Tedeschi R, Gloghini A, Talamini R, Bortolin MT, Berretta M, Spina M, Morassut S, Vaccher E, De Paoli P, Carbone A, Tirelli U. Plasma HHV-8 viral load in HHV8-related lymphoproliferative disorders associated with HIV infection. J Med Virol. 2009; 81:888-896. https://doi. org/10.1002/jmv.21349.

25. Carbone A, Vaccher E, Gloghini A, Pantanowitz L, Abayomi A, de Paoli P, Franceschi S. Diagnosis and management of lymphomas and other cancers in HIV-infected patients. Nat Rev Clin Oncol. 2014; 11:223-238. https://doi.org/10.1038/ nrclinonc.2014.31.

26. Nunnari G, Gussio M, Pinzone MR, Martellotta F, Cosentino S, Cacopardo B, Celesia BM. Cryptococcal meningitis in an HIV-1-infected person: relapses or IRIS? Case report and review of the literature. Eur Rev Med Pharmacol Sci. 2013; 17:1555-1559.

27. Berretta M, Martellotta F, Simonelli C, Di Benedetto F, De Ruvo N, Drigo A, Bearz A, Spina M, Zanet E, Berretta S, Tirelli U. Cetuximab/targeted chemotherapy in an HIVpositive patient with metastatic colorectal cancer in the HAART era: a case report. J Chemother. 2007; 19:343-346. https://doi.org/10.1179/joc.2007.19.3.343.

28. Di Benedetto F, De Ruvo N, Berretta M, Masetti M, Montalti R, Di Sandro S, Quintini C, Codeluppi M, Tirelli U. Don't Deny Liver Transplantation to HIV Patients With Hepatocellular Carcinoma in the Highly Active Antiretroviral Therapy Era. J Clin Oncol. 2006; 24:e26e27. https://doi.org/10.1200/JCO.2006.06.1374.

29. Pinzone MR, Cacopardo B, Condorelli F, Di Rosa M, Nunnari G. Sirtuin-1 and HIV-1: An Overview. Current
Drug Targets. 2013; 14:648-652. https://doi.org/10.2174/1 389450111314060005 .

30. Nasti G, Martellotta F, Berretta M, Mena M, Fasan M, Di Perri G, Talamini R, Pagano G, Montroni M, Cinelli R, Vaccher E, Monforte AD, Tirelli U. Impact of highly active antiretroviral therapy on the presenting features and outcome of patients with acquired immunodeficiency syndrome-related Kaposi sarcoma. Cancer. 2003; 98:24402446. https://doi.org/10.1002/cncr.11816.

31. Nunnari G, Pomerantz RJ. IL-7 as a potential therapy for HIV-1-infected individuals. Expert Opin Biol Ther. 2005; 5:1421-1426. https://doi.org/10.1517/14712598.5.11.1421.

32. Di Rosa M, Malaguarnera G, De Gregorio C, Palumbo M, Nunnari G, Malaguarnera L. Immuno-modulatory effects of vitamin D3 in human monocyte and macrophages. Cell Immunol. 2012; 280:36-43. https://doi.org/10.1016/j. cellimm.2012.10.009.

33. Berretta M, Cinelli R, Martellotta F, Spina M, Vaccher E, Tirelli U. Therapeutic approaches to AIDS-related malignancies. Oncogene. 2003; 22:6646-6659. https://doi. org/10.1038/sj.onc.1206771.

34. Pinzone MR, Nunnari G. Prevalence of comorbidities in a cohort of women living with HIV. Infect Dis Trop Med. 2015; 1:e165.

35. Bellissimo F, Pinzone MR, Cacopardo B, Nunnari G. Diagnostic and therapeutic management of hepatocellular carcinoma. World J Gastroenterol. 2015; 21:12003-12021. https://doi.org/10.3748/wjg.v21.i42.12003.

36. Nunnari $G$, Otero $M$, Dornadula $G$, Vanella $M$, Zhang H, Frank I, Pomerantz RJ. Residual HIV-1 disease in seminal cells of HIV-1-infected men on suppressive HAART: Latency without on-going cellular infections. AIDS. 2002; 16:39-45. https://doi. org/10.1097/00002030-200201040-00006.

37. Zanet E, Berretta M, Martellotta F, Cacopardo B, Fisichella R, Tavio M, Berretta S, Tirelli U. Anal Cancer: Focus on HIV-Positive Patients in the HAART Era. Curr HIV Res. 2011; 9:70-81. https://doi. org/10.2174/157016211795569087.

38. Dornadula G, Nunnari G, Vanella M, Roman J, Babinchak T, DeSimone J, Stern J, Braffman M, Zhang H, Pomerantz RJ. Human immunodeficiency virus type 1-infected persons with residual disease and virus reservoirs on suppressive highly active antiretroviral therapy can be stratified into relevant virologic and immunologic subgroups. J Infect Dis. 2001; 183:1682-1687. https://doi.org/10.1086/320715.

39. Castronuovo D, Cacopardo B, Pinzone MR, Di Rosa M, Martellotta F, Schioppa O, Moreno S, Nunnari G. Bone disease in the setting of HIV infection: update and review of the literature. Eur Rev Med Pharmacol Sci. 2013; 17:2413-2419.

40. Montrucchio C, Biagini R, Alcantarini C, Calcagno A, Barco A, Ferrara M, Milesi M, Costa C, Trentalange A, Trunfio M, Tettoni MC, Grosso Marra W, D'Ascenzo F, et 
al. Cardiovascular risk and neurocognitive deficits in HIVpositive individuals. Infect Dis Trop Med. 2017; 3:e370.

41. D'Aleo F, Ceccarelli M, Venanzi Rullo E, Facciolà A, Di Rosa M, Pinzone MR, Condorelli F, Visalli G, Picerno I, Berretta M, Pellicanò GF, Nunnari G. Hepatitis C-related hepatocellular carcinoma: diagnostic and therapeutic management in HIV-patients. Eur Rev Med Pharmacol Sci. 2017; 21:5859-5867.

42. Nunnari G, Xu Y, Acheampong EA, Fang J, Daniel R, Zhang C, Zhang H, Mukhtar M, Pomerantz RJ. Exogenous IL-7 induces Fas-mediated human neuronal apoptosis: potential effects during human immunodeficiency virus type 1 infection. J Neurovirol. 2005; 11:319-328. https:// doi.org/10.1080/13550280500187005.

43. Berretta M, Di Francia R, Stanzione B, Facchini G, Lleshi A, de Paoli P, Spina M, Tirelli U. New treatment strategies for HIV-positive cancer patients undergoing antiblastic chemotherapy. Expert Opin Pharmacother. 2016; 17:23912403. https://doi.org/10.1080/14656566.2016.1252332.

44. Pinzone MR, Fiorica F, Di Rosa M, Malaguarnera G, Malaguarnera L, Cacopardo B, Zanghì G, Nunnari G. NonAIDS-defining cancers among HIV-infected people. Eur Rev Med Pharmacol Sci. 2012; 16:1377-1388.

45. La Ferla L, Pinzone MR, Nunnari G, Martellotta F, Lleshi A, Tirelli U, De Paoli P, Berretta M, Cacopardo B. Kaposi' s sarcoma in HIV-positive patients: the state of art in the HAART-era. Eur Rev Med Pharmacol Sci. 2013; 17:2354-2365.

46. Berretta M, Zanet E, Taibi R, Martellotta F, Pavone P, Bearz A, Gobitti C, Ciancia EM, Canzonieri V, Tirelli U. Leiomyosarcoma of the parotid gland in an HIV-positive patient: therapeutic approach, clinical course and review of the literature. J Chemother. 2009; 21:215-218. https:/doi. org/10.1179/joc.2009.21.2.215.

47. Ceccarelli G, Vassalini P, Corano Scheri G, Cavallari EN, Bianchi L, Di Girolamo G, Fratino M, Vullo V, D'Ettorre G. Improvement of neuropsychological performances and reduction of immune-activation markers after probiotic supplementation and change of life-style in an HIV positive male: targeting the microbiota to act on gut-brain axis. Infect Dis Trop Med. 2017; 3:e404.

48. Scarpino M, Pinzone MR, Di Rosa M, Madeddu G, Focà E, Martellotta F, Schioppa O, Ceccarelli G, Celesia BM, D'Ettorre G, Vullo V, Berretta S, Cacopardo B, Nunnari G. Kidney disease in HIV-infected patients. Eur Rev Med Pharmacol Sci. 2013; 17:2660-2667.

49. Visalli G, Paiardini M, Chirico C, Cervasi B, Currò M, Ferlazzo N, Bertuccio MP, Favaloro A, Pellicanò G, Sturniolo G, Spataro P, Ientile R, Picerno I, Piedimonte G. Intracellular accumulation of cell cycle regulatory proteins and nucleolin re-localization are associated with pre-lethal ultrastructural lesions in circulating $\mathrm{T}$ lymphocytes: the HIV-induced cell cycle dysregulation revisited. Cell Cycle. 2010; 9:2130-2140. https://doi.org/10.4161/cc.9.11.11754.
50. Trovato M, Ruggeri RM, Sciacchitano S, Vicchio TM, Picerno I, Pellicanò G, Valenti A, Visalli G. Serum interleukin-6 levels are increased in HIV-infected patients that develop autoimmune disease during long-term follow-up. Immunobiology. 2018; 223:264-268. https://doi. org/10.1016/j.imbio.2017.10.039.

51. Canzonieri V, Alessandrini L, Caggiari L, Perin T, Berretta M, Cannizzaro R, De Re V. Hepatocellular Carcinoma: an overview of clinico-pathological and molecular perspectives. WCRJ. 2015; 2:e485.

52. Berretta M, Zanet E, Di Benedetto F, Simonelli C, Bearz A, Morra A, Bonanno S, Berretta S, Tirelli U. Unusual presentation of metastatic hepatocellular carcinoma in an HIV/HCV coinfected patient: case report and review of the literature. Tumori. 2008; 94:589-591. https://doi. org/10.1700/371.4344.

53. Nunnari G, Sullivan J, Xu Y, Nyirjesy P, Kulkosky J, Cavert W, Frank I, Pomerantz RJ. HIV type 1 cervicovaginal reservoirs in the era of HAART. AIDS Res Hum Retroviruses. 2005; 21:714-718. https://doi.org/10.1089/ aid.2005.21.714.

54. Visalli G, Bertuccio MP, Currò M, Pellicanò G, Sturniolo G, Carnevali A, Spataro P, Ientile R, Picerno I, Cavallari V, Piedimonte G. Bioenergetics of $\mathrm{T}$ cell activation and death in HIV type 1 infection. AIDS Res Hum Retroviruses. 2012; 28:1110-1118. https://doi.org/10.1089/AID.2011.0197.

55. Nunnari G, Smith JA, Daniel R. HIV-1 Tat and AIDSassociated cancer: targeting the cellular anti-cancer barrier? J Exp Clin Cancer Res. 2008; 27:3. https://doi. org/10.1186/1756-9966-27-3.

56. Colafigli M, Bonadies A, Ferraresi V, Tonachella R, Cristaudo A, Latini A. Kaposi Sarcoma in HIV-infected patients: an infectious-dermatological outpatient service experience. Infect Dis Trop Med. 2017; 3:e410.

57. Di Benedetto F, Di Sandro S, De Ruvo N, Berretta M, Montalti R, Guerrini GP, Ballarin R, De Blasiis MG, Spaggiari M, Smerieri N, Iemmolo RM, Guaraldi G, Gerunda GE. Human immunodeficiency virus and liver transplantation: our point of view. Transplant Proc. 2008; 40:1965-1971. https://doi.org/10.1016/j. transproceed.2008.05.067.

58. Di Benedetto F, Di Sandro S, De Ruvo N, Berretta M, Masetti M, Montalti R, Ballarin R, Cocchi S, Potenza L, Luppi M, Gerunda GE. Kaposi's sarcoma after liver transplantation. J Cancer Res Clin Oncol. 2007; 134:653658. https://doi.org/10.1007/s00432-007-0329-3.

59. Tavio M, Grossi P, Baccarani U, Scudeller L, Pea F, Berretta M, Adani G, Vivarelli M, Riva A, Tirelli U, Bresadola V, Viale P, Risaliti A. HIV-Infected Patients and Liver Transplantation: Who, When and Why. Curr HIV Res. 2011; 9:120-127. https://doi.org/10.2174/157016211795569159.

60. Martellotta F, Berretta M, Vaccher E, Schioppa O, Zanet E, Tirelli U. AIDS-Related Kaposis Sarcoma: State of the Art 
and Therapeutic Strategies. Curr HIV Res. 2009; 7:634-638. https://doi.org/10.2174/157016209789973619.

61. Nunnari G, Leto D, Sullivan J, Xu Y, Mehlman KE, Kulkosky J, Pomerantz RJ. Short Communication:Seminal Reservoirs during an HIV Type 1 Eradication Trial. AIDS Res Hum Retroviruses. 2005; 21:768-775. https://doi. org/10.1089/aid.2005.21.768.

62. Zanet E, Berretta M, Di Benedetto F, Talamini R, Ballarin R, Nunnari G, Berretta S, Ridolfo A, Lleshi A, Zanghi A, Cappellani A, Tirelli U. Pancreatic Cancer in HIV-Positive Patients. Pancreas. 2012; 41:1331-1335. https://doi. org/10.1097/mpa.0b013e31824a0e40.

63. Wang FX, Xu Y, Sullivan J, Souder E, Argyris EG, Acheampong EA, Fisher J, Sierra M, Thomson MM, Najera R, Frank I, Kulkosky J, Pomerantz RJ, Nunnari G. IL-7 is a potent and proviral strain-specific inducer of latent HIV-1 cellular reservoirs of infected individuals on virally suppressive HAART. J Clin Invest. 2005; 115:128-137. https://doi.org/10.1172/jci200522574.

64. Calcagno A, Simiele M, Alberione MC, Bracchi M, Marinaro L, Ecclesia S, Di Perri G, D'Avolio A, Bonora S. Cerebrospinal fluid inhibitory quotients of antiretroviral drugs in HIV-infected patients are associated with compartmental viral control. Clin Infect Dis. 2014; 60:311317. https://doi.org/10.1093/cid/ciu773.

65. Visalli $\mathrm{G}$, Currò $\mathrm{M}$, Facciolà $\mathrm{A}$, Riso $\mathrm{R}$, Mondello $\mathrm{P}$, Laganà P, Di Pietro A, Picerno I, Spataro P. Prevalence of human papillomavirus in saliva of women with HPV genital lesions. Infect Agent Cancer. 2016; 11:48. https://doi. org/10.1186/s13027-016-0096-3.

66. Kahn JA, Rudy BJ, Xu J, Kapogiannis B, Secord E, Gillison M. Prevalence and risk factors for oral DNA tumor viruses in HIV-infected youth. J Med Virol. 2016; 88:1944-1952. https://doi.org/10.1002/jmv.24555.

67. Patton LL, Ramirez-Amador V, Anaya-Saveedra G, Nittayananta W, Carrozzo M, Ranganathan K. Urban legends series: oral manifestations of HIV infection. Oral Dis. 2013; 19:533-550. https://doi.org/10.1111/odi.12103.

68. Beachler DC, Weber KM, Margolick JB, Strickler HD, Cranston RD, Burk RD, Wiley DJ, Minkoff H, Reddy S, Stammer EE, Gillison ML, D'Souza G. Risk factors for acquisition and clearance of oral human papillomavirus infection among HIV-infected and HIV-uninfected adults. Am J Epidemiol. 2014; 181:40-53. https://doi.org/10.1093/ aje/kwu247.

69. D’Souza G, Carey TE, William WN, Nguyen ML, Ko EC, Riddell J, Pai SI, Gupta V, Walline HM, Lee JJ, Wolf GT, Shin DM, Grandis JR, Ferris RL. Epidemiology of head and neck squamous cell cancer among HIV-infected patients. J Acquir Immune Defic Syndr. 2013; 65:603-610. https://doi. org/10.1097/QAI.0000000000000083.

70. Cameron JE, Mercante D, O'Brien M, Gaffga AM, Leigh JE, Fidel PL, Hagensee ME. The Impact of Highly Active Antiretroviral Therapy and Immunodeficiency on Human Papillomavirus Infection of the Oral Cavity of
Human Immunodeficiency Virus-Seropositive Adults. Sex Transm Dis. 2005; 32:703. https://doi.org/10.1097/01. olq.0000175398.34610.2e.

71. Lilly EA, Cameron JE, Shetty KV, Leigh JE, Hager $\mathrm{S}$, McNulty KM, Cheeks C, Hagensee E, Fidel PL. Lack of evidence for local immune activity in oral hairy leukoplakia and oral wart lesions. Oral Microbiol Immunol. 2005; 20:154-162. https://doi. org/10.1111/j.1399-302X.2005.00198.x.

72. Adamopoulou M, Vairaktaris E, Panis V, Nkenke E, Neukam FW, Yapijakis C. HPV detection rate in saliva may depend on the immune system efficiency. In Vivo. 2008; 22:599-602.

73. Cherry-Peppers G, Daniels CO, Meeks V, Sanders CF, Reznik D. Oral manifestations in the era of HAART. J Natl Med Assoc. 2003; 95:21S-32S.

74. Reichart PA. Clinical management of selected oral fungal and viral infections during HIV-disease. Int Dent J. 2000; 49:251-259.

75. Younai FS. Current Trends in the Incidence and Presentation of Oropharyngeal Cancer. J Calif Dent Assoc. 2016; 44:93-100.

76. Tugizov SM, Webster-Cyriaque JY, Syrianen S, Chattopadyay A, Sroussi H, Zhang L, Kaushal A. Mechanisms of viral infections associated with HIV: workshop 2B. Adv Dent Res. 2011; 23:130-136. https:// doi.org/10.1177/0022034511400076.

77. Chaiyachati K, Cinti SK, Kauffman CA, Riddell J. HIVinfected patients with anal carcinoma who subsequently developed oral squamous cell carcinoma: report of 2 cases. J Int Assoc Physicians AIDS Care (Chic). 2008; 7:306-310. https://doi.org/10.1177/1545109708327490.

78. Kreuter A, Wieland U. Human papillomavirus-associated diseases in HIV-infected men who have sex with men. Curr Opin Infect Dis. 2009; 22:109-114. https://doi.org/10.1097/ QCO.0b013e3283229fc8.

79. Beachler DC, Abraham AG, Silverberg MJ, Jing Y, Fakhry C, Gill MJ, Dubrow R, Kitahata MM, Klein MB, Burchell AN, Korthuis PT, Moore RD, D'Souza G. Incidence and risk factors of HPV-related and HPV-unrelated Head and Neck Squamous Cell Carcinoma in HIV-infected individuals. Oral Oncol. 2014; 50:1169-1176. https://doi.org/10.1016/j. oraloncology.2014.09.011.

80. Moyano S, Ordi J, Caballero M, Garcia F, Diaz A, De Sanjose S, Cardesa A, Alos L. Laryngeal squamous cell carcinoma in HIV-positive patients: lack of association with human papillomavirus infection. HIV Med. 2009; 10:634639. https://doi.org/10.1111/j.1468-1293.2009.00737.x.

81. Ciarrocca K, Jackson LL, De Rossi SS. Human papillomavirus: the fundamentals of HPV for oral health care providers. J Calif Dent Assoc. 2013; 41:349-355.

82. Kreimer AR, Alberg AJ, Daniel R, Gravitt PE, Viscidi R, Garrett ES, Shah KV, Gillison ML. Oral human papillomavirus infection in adults is associated with sexual 
behavior and HIV serostatus. J Infect Dis. 2004; 189:686698. https://doi.org/10.1086/381504.

83. Pinheiro R dos S, de França TR, Ferreira D de C, Ribeiro CM, Leao JC, Castro GF. Human papillomavirus in the oral cavity of children. J Oral Pathol Med. 2011; 40:121-126. https://doi.org/10.1111/j.1600-0714.2010.00954.x.

84. Lam JO, Sugar EA, Cranston RD, Weber KM, Burk RD, Wiley DJ, Reddy S, Margolick JB, Strickler HD, Wentz A, Jacobson L, Coles CL, Bream JH, et al. The association of medication use with clearance or persistence of oral HPV infection. Cancer Causes Control. 2016; 27:1491-1498. https://doi.org/10.1007/s10552-016-0826-2.

85. Syrjänen S. Human papillomavirus infection and its association with HIV. Adv Dent Res. 2011; 23:84-9. https:// doi.org/10.1177/0022034511399914.

86. Hille JJ, Webster-Cyriaque J, Palefski JM, Raab-Traub N. Mechanisms of expression of HHV8, EBV and HPV in selected HIV-associated oral lesions. Oral Dis. 2002; 8:161-168.

87. Walline HM, Careu TE, Goudsmit CM, Bellille EL, D'Souza G, Peterson LA, McHugh JB, Pai SI, Lee JJ, Shin DM, Ferris RL. High-Risk HPV, Biomarkers, and Outcome in Matched Cohorts of Head and Neck Cancer Patients Positive and Negative for HIV. Mol Cancer Res. 2016; 15:179-188. https://doi.org/10.1158/1541-7786. MCR-16-0255.

88. Infante-Cossio $\mathrm{P}$, Gonzalo $\mathrm{DH}$, Hernandez-Gutierrez J, Borrero-Martin JJ. Oral inverted ductal papilloma associated with condyloma acuminata and HPV in an HIV+ patient. Int J Oral Maxillofac Surg. 2008; 37:1159-1161. https://doi.org/10.1016/j.ijom.2008.07.016.

89. Beachler DC, D'Souza G, Sugar EA, Xiao W, Gillison ML. Natural history of anal vs oral HPV infection in HIVinfected men and women. J Infect Dis. 2013; 208:330-339. https://doi.org/10.1093/infdis/jit170.

90. Anaya-Saavedra G, Flores-Moreno B, Garcia-Carranca A, Irigoyen-Camacho E, Guido-Jiménez M, Ramirez-Amador V. HPV oral lesions in HIV-infected patients: the impact of long-term HAART. J Oral Pathol Med. 2012; 42:443-449. https://doi.org/10.1111/jop.12032.

91. Chaturvedi AK, Madeleine MM, Biggar RJ, Engels EA. Risk of human papillomavirus-associated cancers among persons with AIDS. J Natl Cancer Inst. 2009; 101:11201130. https://doi.org/10.1093/jnci/djp205.

92. Kreimer AR, Alberg AJ, Viscidi R, Gillison ML. Gender Differences in Sexual Biomarkers and Behaviors Associated With Human Papillomavirus-16, -18, and -33
Seroprevalence. Sex Transm Dis. 2004; 31:247. https://doi. org/10.1097/01.olq.0000118425.49522.2c.

93. Beachler DC, Weber KM, Margolick JB, Strickler HD, Cranston RD, Burk RD, Wiley DJ, Minkoff H, Reddy S, Stammer EE, Gillison ML, D'Souza G. Risk factors for oral HPV infection among a high prevalence population of HIV-positive and at-risk HIV-negative adults. Cancer Epidemiol Biomarkers Prev. 2012; 21:122-33. https://doi. org/10.1158/1055-9965.EPI-11-0734.

94. Shaw R, Beasley N. Aetiology and risk factors for head and neck cancer: United Kingdom National Multidisciplinary Guidelines. J Laryngol Otol. 2016; 130:S9-S12. https://doi. org/10.1017/S0022215116000360.

95. Del Mistro A, Baboci L, Frayle-Salamanca H, Trevisan R, Bergamo E, Lignitto L, Sasset L, Cecchetto MG, Cattelan $\mathrm{AM}$, Calabrò ML. Oral human papillomavirus and human herpesvirus- 8 infections among human immunodeficiency virus type 1-infected men and women in Italy. Sex Transm Dis. 2012; 39:894-898. https://doi.org/10.1097/ OLQ.0b013e31826ef2da.

96. Kreuter A, Brockmeyer NH, Altmeyer P, Pfister H, Wieland U. Rapid onset of multifocal human papillomavirus 72-associated oral intraepithelial neoplasia in a human immunodeficiency virus-infected patient. Br J Dermatol. 2007; 157:826-828. https://doi.org/10.1111/j.1365-2133.2007.08097.x.

97. Casariego Z, Micinquevich S, Gomez MA. HPV in "carcinoma in situ" associated with HIV/AIDS infection: a case report. Med Oral. 2002; 7:84-88.

98. Anderson KM, Allen CM, Nuovo GJ. Human papillomavirus, type 40-associated papilloma, and concurrent Kaposi's sarcoma involving the anterior hard palate of an HIV-positive man. Oral Surg Oral Med Oral Pathol Oral Radiol Endod. 2003; 95:80-84. https://doi.org/10.1067/moe.2003.46.

99. Regezi JA, Dekker NP, Ramos DM, Li X, Macabeo-Ong M, Jordan RC. Proliferation and invasion factors in HIVassociated dysplastic and nondysplastic oral warts and in oral squamous cell carcinoma: an immunohistochemical and RT-PCR evaluation. Oral Surg Oral Med Oral Pathol Oral Radiol Endod. 2002; 94:724-731. https://doi.org/10.1067/ moe.2002.129760.

100. Ammatuna P, Campisi G, Giovannelli L, Giambelluca D, Alaimo C, Mancuso S, Margiotta V. Presence of EpsteinBarr virus, cytomegalovirus and human papillomavirus in normal oral mucosa of HIV-infected and renal transplant patients. Oral Dis. 2001; 7:34-40. 